\title{
Antecedents of Trust in E-Government: Palestinian Citizens' Perspective
}

\author{
MAAN ALI ALKATEEB ${ }^{1}$, RANIA AHMAD ABDALLA ${ }^{2}$ \\ ${ }^{1}$ Industrial Management Department, Business School. PALESTINE TECHNICAL UNIVERSITY-KADOORIE. \\ PALESTINIAN. E-mail: m.khateeb@ptuk.edu.ps. \\ ORCID: http://orcid.org/0000-0002-1626-2916 \\ ${ }^{2}$ Department, Palestine Technical College. PALESTINE TECHNICAL UNIVERSITY-KADOORIE. PALESTINIAN. \\ E-mail: r.alkhateeb@ptuk.edu.ps, ORCID: http://orcid.org/0000-0001-8091-1143
}

\begin{abstract}
Many countries in the Middle East region are adopting the e-government portals to provide services to the citizens. Citizens should be satisfied with these portals and judge them as trustworthy in order to participate in the e-government activities as a primary stakeholder. This study aims to investigate the antecedents of trust in e-government in Palestine from citizens' perspective. The proposed model consisted of four main constructs including technical, governmental, risk factors, and propensity to trust in technology, in addition to five demographic characteristics (age, gender, educational level, income, and internet experience). A closed question questionnaire was designed to collect data, 340 valid questionnaires were retrieved. Simple and Multiple regression analysis were used to build an adequate model. Findings revealed that each construct has separately influenced trust level in e-government, but when combined together, technical and governmental factors have positive influence on citizens' trust level in e-government services, risk factors have a negative influence, whereas the influence of propensity to trust was eliminated. Surprisingly, demographic characteristics showed no statistically significant differences in the level of citizens' trust in e-government. These findings may help government official in improving e-government services by enhancing security measures adopted on the e-government portals thus encouraging citizens to use these services
\end{abstract}

Keywords: E-government; Risk factors; Technical factors; Governmental factors; Propensity to trust in technology

JEL Classification: M38, O33, O35

Received: March 29, 2021

Accepted: June 12, 2021 


\title{
Antecedentes de la Confianza en la Administración Electrónica: Perspectiva de los Ciudadanos Palestinos
}

\author{
MAAN ALI ALKATEEB ${ }^{1}$, RANIA AHMAD ABDALLA ${ }^{2}$ \\ ${ }^{1}$ Industrial Management Department, Business School. PALESTINE TECHNICAL UNIVERSITY-KADOORIE. \\ PALESTINIAN.E-mail: m.khateeb@ptuk.edu.ps. \\ ORCID: http://orcid.org/0000-0002-1626-2916 \\ ${ }^{2}$ Department, Palestine Technical College. PALESTINE TECHNICAL UNIVERSITY-KADOORIE. PALESTINIAN. \\ E-mail: r.alkhateeb@ptuk.edu.ps, ORCID: http://orcid.org/0000-0001-8091-1143
}

\begin{abstract}
RESUMEN
Muchos países de la región de Oriente Medio están adoptando los portales de administración electrónica para prestar servicios a los ciudadanos. Los ciudadanos deben estar satisfechos con estos portales y juzgarlos como dignos de confianza para poder participar en las actividades de la administración electrónica como parte interesada principal. Este estudio pretende investigar los antecedentes de la confianza en la administración electrónica en Palestina desde la perspectiva de los ciudadanos. El modelo propuesto se compone de cuatro constructos principales que incluyen los factores técnicos, gubernamentales, de riesgo y la propensión a confiar en la tecnología, además de cinco características demográficas (edad, género, nivel educativo, ingresos y experiencia en Internet). Se diseñó un cuestionario de preguntas cerradas para recoger los datos, y se recuperaron 340 cuestionarios válidos. Se utilizó el análisis de regresión simple y múltiple para construir un modelo adecuado. Los resultados revelaron que cada constructo ha influido por separado en el nivel de confianza en la administración electrónica, pero cuando se combinan, los factores técnicos y gubernamentales tienen una influencia positiva en el nivel de confianza de los ciudadanos en los servicios de administración electrónica, los factores de riesgo tienen una influencia negativa, mientras que la influencia de la propensión a la confianza se eliminó. Sorprendentemente, las características demográficas no mostraron diferencias estadísticamente significativas en el nivel de confianza de los ciudadanos en la administración electrónica. Estos resultados pueden ayudar a los funcionarios a mejorar los servicios de la administración electrónica mediante la mejora de las medidas de seguridad adoptadas en los portales de la administración electrónica, animando así a los ciudadanos a utilizar estos servicios.
\end{abstract}

Palabras claves: Gobierno electrónico; Factores de riesgo; Factores técnicos; Factores gubernamentales; Propensión a confiar en la tecnología.

JEL Classification: M38, O33, O35 


\section{Introduction}

Palestinian government like many other governments in the Middle Eastregion has digitized a largeportion of its public services in an attempt to interact more efficiently with the citizens through electronic channels. During the past two decades, the role of information technology (IT) has grown in an accelerating rate worldwide and the use of electronic services has become the standard for the public sector in judging the performance of governments in transactions processes (Rehouma\& Hofmann, 2018).

E-services provided by e-government have a crucial influence on citizens' lives and their relationship with governments (Abu-Shanab, 2014). Adoptionof e-government yields many advantages to governments such as reducing service delivery cost, improving operations efficiency, and improving services quality (Rana \&Dwivedi, 2015; Abu-Shanab, 2017). On the other hand, egovernment provides opportunities for citizen participation to achievesocial, economic and political development. This participation is subject to the extent of citizens' trust in e-government (AbuShanab, 2019). However, in many countries particularly developing countries citizens still do not use online services due to the lack of trust in e-government applications (Alzahrani, Al-Karaghouli, \& Weerakkody,2017). According toAlAwadhi (2019) citizens' trust in governmentswas declining during the past two decades due to various reasons such aslack of transparency, political and administrative corruption and policy failures. This has had a negative influence on their perception towards engagement in e-government services (Saeed et al 2018).

Governments, in both developed and developing countries need to identify thepotential factors that might have an influence on e-government adoption to implement an e-government strategy (Alomari, Sandhu, \& Woods, 2009).Although, there is plenty of research that have examined the relationship between citizens' adoption of e-government and citizens' trust in e-government (Morgeson, VanAmburg, \&Mithas,2010;AlAwadhi, 2019),Akbar (2015) Concluded that trust is the main issue that contributes to the diffusion of e-government. The existing studies has not filled the gap in explaining the factors that enhance citizens' trust and engagement in e-government. Moreover, the gap in the developing countries is wider (Alomari, Sandhu \& Woods, 2014). The importance of this study comes from the fact the success of e-government concept is mainly depending on the citizens' trust in using the provided services through e-government website. It is expected that the essential factors that may influence citizens' trust in e-government adoption in the Arab World could be different from those associated with Western countries (Obaid et al, 2020). Therefore, this study aims to explore those factors that may influence citizens' trust in e-government in an attempt to fill the gap in the available literature. The findings of the current study forms a basis for future developments of effective e-government procedures and strategies that in turn lead to a higher level of citizens' trust in the services provided by e-government.

The structure of this paper after the introduction section will be as follows: Section 2 will explore the related literature and propose the research model, while section 3 will present the research methodology. Section 4 will report data analysis results. Discussion is presentedin section 5 , and finally conclusion is drawn in section 6 .

\section{Literature Review}

\subsection{E-Government}

With the wide spread of the internet technology most countries have introduced the concept of e-government in their national plans (Singh, Das, \& Joseph, 2007). A large number of definitions of egovernment exist in the relevant literature depending on the context in which it is applied. According to(Yildiz, 2007), three problems are evident in literature,first is the large number of definitions that are normative, the second problem is related to those definitions which are too narrow, and the third problem refers to the ambiguity of some definitions. Regardless of these problems, Yildiz (2007) argued that there are some definitions emphasize the different facets of e-government concept. For 
example, Mensah \& Mi (2019) defined e-government as the application of Informationand Communication Technologies (ICTs) by the government administration systems to ensure and improve interactivity with citizens to provide an efficient and effective delivery of public services to match the expectations of the citizens. Similarly, Santhanamery\&Ramayah (2018) defined egovernment as the applications ofICT, and other communications tools such as mobiles and internet to deliver necessary services to citizens, enhance government agencies performance, to improve public participation and to strengthen relations with citizens, business and other agencies of government. Mensah \&Mi (2018) in reviewing definitions of e-governmentindicated thatsix themes areimplicated in these definitions. First, e-government is about application of Information and Communication Technologies (ICTs); secondly, it is mainly concerned withpublic sector management; thirdly, improve thedelivery of public service to citizens andbusinesses; fourthly, it concerns with improvingefficiency, transparency and accountability; fifthly, it aims to e-participation and lastly it is about improving the performance of public sector organizations.Research concerning the implications of e-government has beenincreased at accelerating rate due to the growing interest of public administrations in ICTs (Wirtz\&Daiser, 2018). Thus, the continuous advancement in technology offered challenging research questions for academics, mainly what are the major antecedents of citizens' trust in e-government.

\subsection{Trust and E-government}

The concept of trust is very important in building positive relationships and enhancing interactions between different parties (Alzahrani et al. 2017).In e-government context, it becomes more significant due to the lack of physical interaction between the citizens and the employees as they perform their transactions via electronic channels.Al-Samarraie, Teng, Alzahrani, \&Alalwan, (2018) stated that citizens do not trust online services that are provided by governments and prefer personal contact. Nevertheless, trust has been widely investigatedand led tosignificant resultswhen linked to the intention to use e-government services (Abu-Shanab,2017). Although that the concept of trust in e-government is complex as it involves complicated dimensions that have an influence on citizens' trust in government services (Alzahrani et al. 2017), there is an agreement among researchers that trust plays a crucial role in the implementation of e-government (Dwivedi, Weerakkody \& Janssen, 2012; Khasawneh\& Abu-Shanab, 2013; Rana and Dwivedi, 2015; Alzahrani et al. 2017; Veeramootoo, Nunkoo, \& Dwivedi, 2018). Thus, trust is a salient predictor of e-government success (AlAwadhi. 2019; Alzahrani et al. 2017; Abu-Shanab, 2014; Colesca 2009).

Osman, Anouze, Irani, Al-Ayoubi, Lee, Balcı, \&Weerakkody (2014) considered user trust as the primary objective of government services and it replaces the price-related outcome in the private sector. Fakhoury\& Aubert (2015) and Akbar (2015) considered trust as an asset for the adoption of egovernment. On the other hand, Wang \& Lu (2011) argued that citizens' trust in e-government islinked with citizens' trust in the internet. Researchers have identified trust as a primary predictor for technology adoption (Abu-Shanab, 2010, Cetin, Kanat, \& Ozkan, 2011). Similarly, Abu-Shanab (2014) broke down trust into two dimensions, trust in government and trust in the internet.

In the Palestinian context, trust becomes more significant due to the lack of cooperation between different ministries. This overwhelms every ministry that wants to provide electronic services to the public, in addition to providing the required services, it has to guarantee a secure data transfer process as well as and ensuring the privacy of the user (Ayyash, Ahmad, \& Singh, 2013).

\subsection{Antecedents of Trust in E-government (TrstinG)}

New communication technologies and in particular internet websites provide an efficient means for the government to communicate and deliver its services to citizens. Largely, the success of this process depends on public trust in e-government. Thus, it is important to explore those factors that may have an impact on citizens' trust in e-government. Previous research classified antecedents of trust in e-government in different ways. In reviewing the literature (Alzahrani et al., 2017) argued that previous research has concentrated on two dimensions of trust in e-government. These are trust 
in technology and trust in the government itself. The logical basis for this view is that trust in technology and trust in government are the primary components of e-government. This implies that citizens' trust in e-government is subject to their level of trust in the government itself (despite of its electronic services), and their level of trust in technology to perform transactions (despite of their opinion about the government). The availability of these two constructs will convey the overall concept of trust in e-government (Abu-shanab, 2019). Although that the existing research focuses on technology side, the current study considered both dimensions as antecedents of trust in egovernment.

Abu-Shanab (2014) investigated five proposed antecedents of Jordanians' trust in e-government, namely: trust in government, trust in technology, information quality, internet familiarity and privacy and security. The findings revealed that all the five predictors have significantly influenced citizens' trust in e-government. Alzahrani et al, (2017) examined the impact of gender, age, and internet experience on citizens' trust in e-government. The results showed that females have more confidence in online services than males. It also found that old people show greater trust in egovernment than younger people. For the internet experience, the result confirmed the positive influence in trust in online services. Alzahrani, Karaghouli, \&Weerakkody (2016) investigated the influence of technology, government agencies, risk, and citizens' characteristic on citizens' trust in egovernment. The findings showed a significant positiveinfluence of technical factors and citizens' characteristic while government agencies and risk showed negative influence on trust in egovernment. On the other hand, Belanche\&Casaló (2015) argued that trust in government increases trust in e-government and contributes in the adoption of e-government. Similarly, Teo, Srivastava, \& Jiang (2008) found that trust in government is positively related to trust in e-government, while technology factors have no influence. According to Shareef, Kumar, Kumar, \&Dwivedi (2011) uncertainty, security and privacy are the main determinants of trust in e-government. Khan, Rahim, \& Maarop (2018) found that ease of use and usefulness of e-government services are positively impact citizens trust in e-government. Among the most important factors influencing trust in egovernment are the level of security and the risk perceived by users (Ejdys, Ginevicius, Rozsa\&Janoskova, 2019). A study by Beldad, van der Geest, de Jong, \&Steehouder (2012) revealed that confidence in online privacy statements positively influences trust in e-government. Perceived usefulness, perceived ease of use, perceived security and perceived risk, are found to have direct impact on the citizen trust in e-government (Liu, \& Zhou, 2010). In Palestinian context, the sole study found in the literature was conducted byAyyashet al., (2013) which aimed to examine the impact of IS factors trust in e-government adoption in the context of Palestinian government ministries. The findings showed that information quality, system quality, service quality, perceived usefulness, perceived ease of use, and security privacy have positive influence on trust in e-government.

It is obvious from the literature review that most studies have concentrated on technology factors and government factors as antecedents of trust in e-government with less focus on other factors like citizen's characteristics and risk considerations. Only three studies found in the literature concentrated on the four factors (Alzahrani, et al., 2017; Beldad et al. 2012 and Colesca 2009). In this study, the four dimensions are integrated to investigate their influence on trust in e-government along with five demographic characteristics: gender, age, educational level, income, and internet experience.

\subsection{Research Model and Hypotheses Development}

Following the literature review, four constructs are identified as the antecedents of trust in egovernment from the citizens'perspective. These constructs are individuals'characteristics, technical factors, governmental factors, and risk factors. The model is basically based on Alzahrani, et al (2018). 


\subsubsection{Individuals'Characteristics}

Regarding the impact of personal characteristics on trust in e-government very few studies investigated this issue. For example, Colesca (2009) found significant positive impact of some individual factors on trust in e-government such as gender, age, disposition to trust, internet experience, and education. Similarly, Alzahraniet al (2018) argued that citizens' characteristics are positively and significantly affect trust in e-government. Familiarity with internet is one of the most individual characteristics that influences trust in e-government (Abu-Shanab, 2014). Colesca\& Dobrica (2008) added to the previous factors social class as an antecedent to the confidence in egovernment services. Based on this discussion the following hypotheses are proposed:

H1a: Female have more trust in e-government services e-government services than males.

H1b: Younger citizens have more trust in e-government services e-government services than older ones.

H1c: Educational level positively influences citizen' trust in e-government services

H1d: Income positively effects citizens' trust in e-government services

H1e: Internet experience positivelyeffects citizens' trust in e-government services.

\subsubsection{Technical Factors}

Concerning technical factors, a large number of studies emphasize the importance of these factors in enhancing trust in e-government. The majority of research investigated trust in online services considered technical factors as a primary antecedent of trust in e-government (AlAwadhi 2019; Veeramootoo et al,2018; Abu-Shanab, 2017; Alzahrani et al,2016; Ayyash et al., 2013; Khasawneh\& Abu-Shanab, 2013). Different approaches have been used to identify the factors of this construct. For instance, The D\&M model identified three factors: information quality, service quality and system quality. A according to the TAM model usefulness and ease of use are the main factors of technical aspect. This study identified the five factors of both TAM and D\&M model.

H2: Technical factors positively influencecitizens' trust in e-government.

H2a: Perceived usefulness (PU) has a positive impact on citizens' trust in e-government.

H2b: Perceived ease of use (PEOU) has a positive impact on citizens'trust in e-government.

H2c: Information quality (IQ) positively influencescitizens' trust in e-government

H2d: System Quality (SyQ) positively influences citizens' trust in e-government

H2f: Services Quality (SvQ) positively influences citizens' trust in e-government

\subsubsection{Governmenta I Factors}

Governmental factors are related to the level of trust and confidence of the citizens towards the government agencies and their beliefs that the government is capable to provide affective services to their citizens (Alzahrani et al,2016). A Large body of research examined the relationship between government agencies and trust in e-government (Wang \& Lu, 2011; Beldad et al., 2012; Choudrie, Alfalah, \& Spencer 2017; Kurfalı, Arifoğlu, Tokdemir, \&Paçin, 2017; Alzahrani et al,2016). The majority of these studies found a significant and positive influence of trust in government on trust in egovernment. In this study the two dimensions of government agencies suggested by (Alzahrani et al,2018) are adopted: government reputation and past experience. Consequently, the following hypotheses are proposed.

H3: Government agency factors positively influence citizens' trust in e-government.

H3a: Government reputation (GRep) positively influences citizens'trust in e-government

H3b: Past experience (PExp) positively influences citizens' trust in e-government

\subsubsection{Risk Factors}

Risk is mainly concerned with the issue of privacy and security (Alzahrani et al, 2018). A strong relationship was found between risk and trust in r-government in previous literature (Beldad et al, 
2012; Ayyash et al, 2013; Alzahrani et al ,2018; Khan, Rahim \&Maarop, 2019; Mensah,2019). Privacy in e-services context could be defined as the worry about losing control over personal information, whereas security is related to any unauthorized access to the personal data of the individuals (Khan et al, 2019). Providing the e-government website with the necessary security measures and mechanism is not optional, it is critical for its existence and success (Alsmadi, \& Abu-Shanab, 2016). Consequently, the following hypotheses are proposed.

H4: Risk factors negatively influence citizens' trust in e-government.

H4a: Privacy concerns(Pri) negatively influence citizens'trust in e-government

H4b: Security concerns(Sec) negatively influence citizens'trust in e-government

\subsubsection{Propensity to Trust in Technology}

Most researcher studies the concept of propensity to trust in general not in technological context (Beldad et al, 2012; Colesca, 2009; Bélanger\& Carter, 2008). They argue that people who have more propensity to trust in people in general, are most likely to have trust in the e-government. In general context, propensity to trust refers to an individual willingness to rely on other (Colquitt, Brent, Scott, \&LePine, 2007). Trust in technology can be defined as trust in the reliability of the enabling technology (Bélanger and Carter, 2008). Propensity to trust in technology implies that the user believes that the technology used performs the required tasks satisfactorily. In e-government context, trust in technology is essential for its adoption (Srivastava, \&Teo, 2005).

Several studies found strong relationship between propensity to trust in technology and trust in egovernment (Bélanger\& Carter, 2008; Colesca, 2009; Mohajerani, Shahrekordi \& Azarlo, 2015). Based on the above discussion, the following hypotheses is proposed:

H5: Propensity to trust in technology (PTrst) has appositive influence on citizens'trust in egovernment.

The theoretical research model is presented in Figure 1.

Figure 1 Proposed Research Model

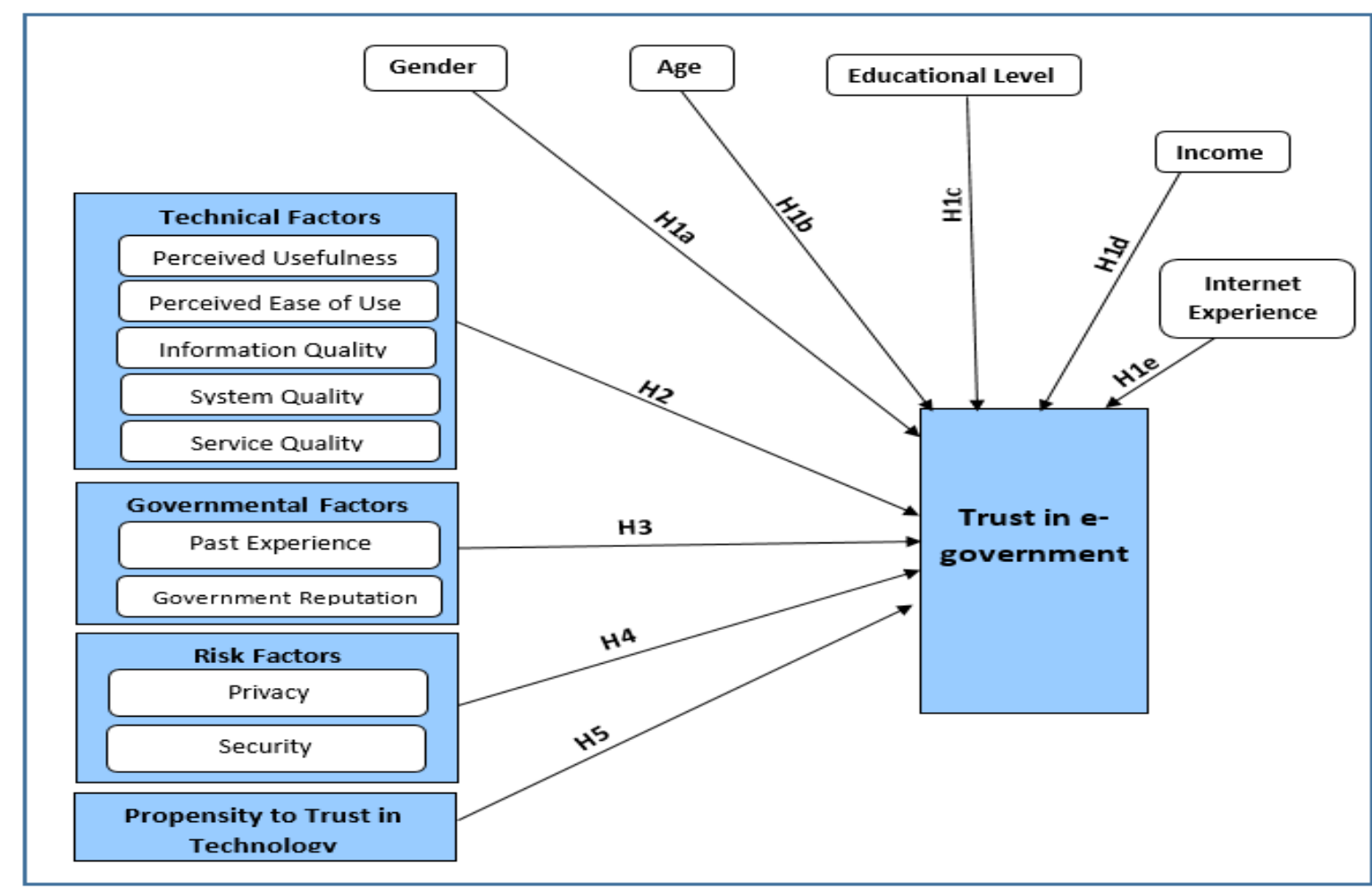

Source Prepared by the researchers 


\section{Data and Methodology}

The study is exploratory in nature. It aims to identify those factors that have an influence on citizens' trust in e-government services. A survey was designed and conducted to assess the proposed model and to examine the relationships between the constructs. Questions' items were selected from previous literature as shown in Table (1). The wording was modified to fit the current study context, each item is rated on Five-point scale ranged from (5: Strongly Agree) to (1: Strongly Disagree). The results were analyzed using regression analysis.

Table 1 Study Items

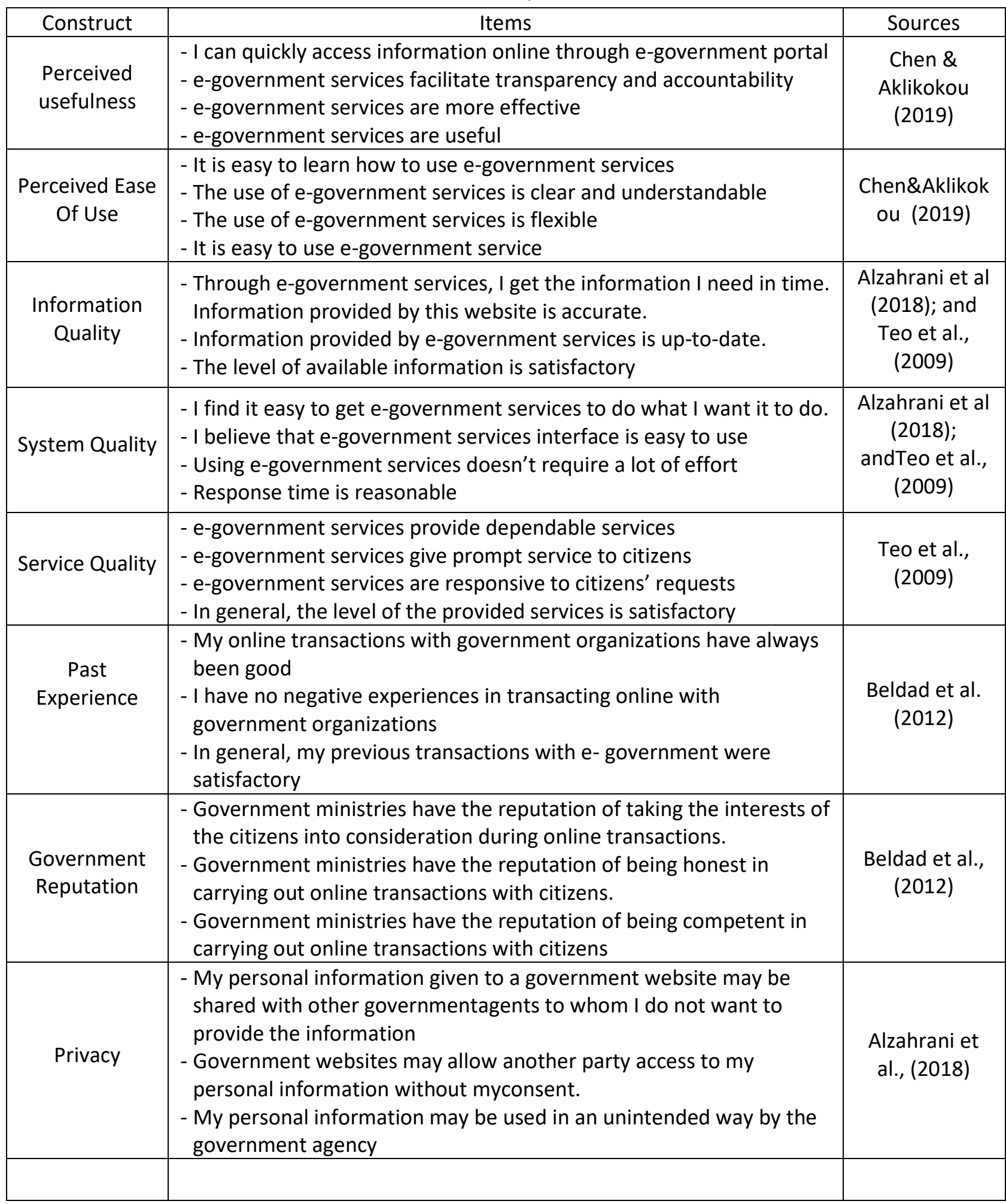




\begin{tabular}{|c|c|c|}
\hline Security & $\begin{array}{l}\text { - Hackers may be able to intrude into government websites and steal } \\
\text { my personal informationstored on the web. } \\
\text { - I would not feel secure sending sensitive information to e- } \\
\text { government websites } \\
\text { - Overall, it is not safe sending sensitive information to e-government } \\
\text { websites }\end{array}$ & Colesca(2009) \\
\hline $\begin{array}{l}\text { Propensity to } \\
\text { Trust in } \\
\text { Technology }\end{array}$ & $\begin{array}{l}\text { - I believe the technologies supporting the system are reliable all the } \\
\text { time } \\
\text { - I believe the technologies supporting the system are secure all the } \\
\text { time } \\
\text { - Overall, I have confidence in the technology used by government } \\
\text { agencies to operate the e-government services }\end{array}$ & Colesca (2009) \\
\hline $\begin{array}{l}\text { Trust in } \\
\text { e-Government }\end{array}$ & $\begin{array}{l}\text { - I expect that e-government services will not take advantage of me. } \\
\text { - I believe that e-government services are trustworthy } \\
\text { - I believe that e-government services will not act in a way that harms } \\
\text { me } \\
\text { - I trust e-government services }\end{array}$ & Colesca (2009) \\
\hline
\end{tabular}

Source: Developed by the researchers based on literature review

\subsection{Reliability}

The reliability of these items was tested using Cronbach Alpha Coefficient as shown in Table (2). All of the coefficient values were above the cutoff value of 0.7 determined by (Nunnaly, 1978) as the acceptance measure for reliability.

Table 2. Cronbach Alpha Coefficient of the suggested model variables

\begin{tabular}{|l|c|c|c|}
\hline Variable & Mean & $\begin{array}{c}\text { Standard } \\
\text { Deviation }\end{array}$ & $\begin{array}{c}\text { Cronbach Alpha } \\
\text { Coefficient }\end{array}$ \\
\hline PU & 3.94 & 0.733 & 0.861 \\
\hline PEOU & 3.89 & 0.867 & 0.856 \\
\hline IQ & 3.81 & 0.870 & 0.862 \\
\hline SyQ & 3.87 & 0.791 & 0.837 \\
\hline SvQ & 3.79 & 0.896 & 0.881 \\
\hline GRep & 3.61 & 0.993 & 0.909 \\
\hline PExp & 3.84 & 0.801 & 0.885 \\
\hline Pri & 2.25 & 0.673 & 0.767 \\
\hline Sec & 3.58 & 1.075 & 0.897 \\
\hline PTrst & 3.62 & 0.902 & 0.876 \\
\hline TrstinG & 3.71 & 0.834 & 0.817 \\
\hline \multicolumn{3}{|c|}{ Total } & $\mathbf{0 . 9 5 1}$ \\
\hline
\end{tabular}

Source: Developed by the researchers based on statistical analysis

\subsection{Sampling}

Palestinian citizens who use e-government services represent the population of this study. However, it is almost impossible to draw a random sample from this population directly as a large portion of ordinary citizens in Palestine may not use such services. Thus, the employees of the two largest governmental agencies weretargeted as the study sample. The questionnaire wasadministered to 400 Palestinian public sector employees selected from the Ministry of Education and the Ministry of Health to represent the Palestinian citizens as they have regular access to the internet and they are the most likely users of governmental services.According to the health annual report 2018 published by the ministry of health in June 2019, the number of employees is 13,950.The number of employees in the Ministry of Education is 47,833 based on the statistics provided by the 
General Personnel Council (2016).Therefore the population size is 61,783 . According to Daniel and Cross (2013) equation, the required sample size that should be drawn from the population at $5 \%$ significance level is 382 . The researchers retrieved 361 questionnaires, 21 were excluded for insufficient filling, yielding 340 valid questionnaires for analysis with response rate $89 \%$.

\section{Results}

\subsection{Demographic Profile:}

Table (3) presents demographic profile of the surveyed citizens:

Table 3 Respondents' Demographic Profile

\begin{tabular}{|c|c|c|c|}
\hline $\begin{array}{c}\text { Demographic } \\
\text { Category }\end{array}$ & Classification & Frequency & Percent \% \\
\hline \multirow{3}{*}{ Gender } & Male & 161 & 47.4 \\
\hline & Female & 179 & 52.6 \\
\hline & Total & 340 & 100 \\
\hline \multirow{5}{*}{ Age } & 20-29 Years & 94 & 27.6 \\
\hline & 30-39 Years & 96 & 28.2 \\
\hline & 40-49 Years & 92 & 27.1 \\
\hline & $>=50$ Years & 58 & 17.1 \\
\hline & Total & 340 & 100 \\
\hline \multirow{5}{*}{$\begin{array}{l}\text { Educational } \\
\text { Level }\end{array}$} & High School & 18 & 5.3 \\
\hline & Diploma & 78 & 22.9 \\
\hline & Bachelor & 179 & 52.6 \\
\hline & Post Graduate Studies & 65 & 19.1 \\
\hline & Total & 340 & 100 \\
\hline \multirow{5}{*}{$\begin{array}{l}\text { Monthly } \\
\text { Income }\end{array}$} & 200-500 JD & 77 & 22.6 \\
\hline & 501-1000 JD & 122 & 35.9 \\
\hline & $1001-1500$ & 83 & 24.4 \\
\hline & $>=1500 \mathrm{JD}$ & 58 & 17.1 \\
\hline & Total & 340 & 100 \\
\hline \multirow{5}{*}{$\begin{array}{l}\text { Internet } \\
\text { Experience }\end{array}$} & Less than one year & 18 & 5.3 \\
\hline & $1-5$ Years & 75 & 22.1 \\
\hline & 6-10 Years & 103 & 30.3 \\
\hline & $>10$ Years & 144 & 42.4 \\
\hline & Total & 340 & 100 \\
\hline
\end{tabular}

As Table (2) illustrates, the population sample is made up of $47.4 \%$ males and $52.6 \%$ females, with $28.2 \%$ of the respondents within the age group of (30-39 years), followed by age group (20-29 years) forming $27.6 \%$, then ( $40-49$ years) with $27.1 \%$ and last comes the age group ( $>=50$ years) with 17.1\%. Regarding the educational level, the majority areholding a Bachelor degree (52.6\%), next are Diploma holders (22.9\%), followed by the employees who hold a Post Graduate Degree (19.1\%), lastly are those with High School Certificate (5.3\%).Concerning monthly income, $35.9 \%$ of the respondents earn 501-1000 JD per month, followed by the respondents with a monthly income of 1001-1500 JD (24.4\%), thirdly, respondents with 200-500 JD per month forming $22.6 \%$ of the study sample, and at last are the respondents with $>=155$ JD with $17.1 \%$. The last demographic characteristic is the internet experience of the employees. $42.4 \%$ of the sample have an experience in using the internet for $>10$ years, next are the respondents with an experience of $6-10$ years $(30.3 \%)$, 
next are the respondents with 1-5 years' experience forming $22.1 \%$ and lastly are those with experience less than one year making $5.3 \%$ of the study sample.

\subsection{Hypotheses Testing}

In order to test the hypotheses, ANOVA analysis is used to test hypotheses $\mathrm{H} 1 \mathrm{a}$ through $\mathrm{H} 1 \mathrm{e}$, since these hypotheses are to examine the existence of statistical differences in respondents' trust level in e-government based on their demographic characteristics. On the other hand, simple linear regression is used to examine the influence of the other constructs on trust in e-government, and finally multiple linear regression is used to examine the overall influence of all of these constructs on trust in e-government.

\subsubsection{ANOVA Analysis (H1a...H1e)}

To test each of the hypotheses related to each of the demographic characteristic, a separate ANOVA test is conducted. Table (4) summarizes the results.

Table 4. ANOVA Analysis Results of the demographic characteristics

\begin{tabular}{|c|c|c|c|c|c|c|}
\hline $\begin{array}{c}\text { Demographic } \\
\text { Category }\end{array}$ & Classification & Mean & $\begin{array}{c}\text { St. } \\
\text { Deviation }\end{array}$ & $\begin{array}{c}\mathbf{F} \\
\text { Value }\end{array}$ & Sig. & Decision \\
\hline \multirow{3}{*}{ Gender } & Male & 3.40 & .504 & \multirow{3}{*}{0.226} & \multirow{3}{*}{0.634} & \multirow{3}{*}{ Reject H1a } \\
\hline & Female & 3.43 & .510 & & & \\
\hline & Total & 3.42 & .507 & & & \\
\hline \multirow{5}{*}{ Age } & 20-29 Years & 3.35 & .512 & \multirow{5}{*}{0.996} & \multirow{5}{*}{0.395} & \multirow{5}{*}{ Reject H1b } \\
\hline & 30-39 Years & 3.45 & .509 & & & \\
\hline & 40-49 Years & 3.38 & .530 & & & \\
\hline & $>=50$ Years & 3.48 & .459 & & & \\
\hline & Total & 3.41 & .507 & & & \\
\hline \multirow{5}{*}{$\begin{array}{l}\text { Educational } \\
\text { Level }\end{array}$} & High School & 3.39 & .543 & \multirow{5}{*}{0.623} & \multirow{5}{*}{0.601} & \multirow{5}{*}{ Reject H1c } \\
\hline & Diploma & 3.39 & .471 & & & \\
\hline & Bachelor & 3.39 & .537 & & & \\
\hline & $\begin{array}{ll}\text { Post } & \text { Graduate } \\
\text { Studies } & \end{array}$ & 3.49 & .455 & & & \\
\hline & Total & 3.42 & .507 & & & \\
\hline \multirow{5}{*}{$\begin{array}{l}\text { Monthly } \\
\text { Income }\end{array}$} & $200-500 \mathrm{JD}$ & 3.35 & .512 & \multirow{5}{*}{0.996} & \multirow{5}{*}{0.395} & \multirow{5}{*}{ Reject H1d } \\
\hline & 501-1000 JD & 3.45 & .509 & & & \\
\hline & $1001-1500$ & 3.38 & .530 & & & \\
\hline & $>=1500 \mathrm{JD}$ & 3.48 & .459 & & & \\
\hline & Total & 3.42 & .507 & & & \\
\hline \multirow{5}{*}{$\begin{array}{c}\text { Internet } \\
\text { Experience }\end{array}$} & Less than one year & 3.21 & .503 & \multirow{5}{*}{1.345} & \multirow{5}{*}{0.260} & \multirow{5}{*}{ Reject H1e } \\
\hline & $1-5$ Years & 3.38 & .469 & & & \\
\hline & $6-10$ Years & 3.46 & .468 & & & \\
\hline & $>10$ Years & 3.43 & .549 & & & \\
\hline & Total & 3.42 & .507 & & & \\
\hline at & $<0.05$ & & & & & \\
\hline
\end{tabular}

As Table (4) shows, no significant statistical differences exist between the surveyed employees based on each of the examined demographic characteristic since the calculated $F$ values were not significant, consequently this leads to reject $\mathrm{H} 1 \mathrm{a}, \mathrm{H} 1 \mathrm{~b}, \mathrm{H} 1 \mathrm{c}, \mathrm{H} 1 \mathrm{~d}$, and $\mathrm{H} 1 \mathrm{e}$. 


\subsubsection{Simple Linear Regression of (H2 ... H5)}

In order to test hypotheses $\mathrm{H} 2, \mathrm{H} 3, \mathrm{H} 4$ and $\mathrm{H} 5$, the researchers conducted a two-step linear regression. First separate influence of each variable in the construct is examined to test the subhypotheses, and then the overall influence of the construct is examined to test the main hypotheses.

\subsubsection{Hypothesis $\mathrm{H}$ 2.}

The second hypothesis consists of five sub-hypotheses ( $\mathrm{H} 2 \mathrm{a}$ through $\mathrm{H} 2 \mathrm{e}$ ). The results of the simple linear regression of each of these sub-hypotheses as well as the overall impact of Technical Factors are shown in Table (5).

Table 5. Simple Linear Regression results of $\mathrm{H}_{2}$

\begin{tabular}{|c|c|c|c|c|c|c|c|c|c|}
\hline Variable & $R^{2}$ & $\begin{array}{c}\text { Adjuste } \\
\mathrm{d} \mathrm{R}^{2}\end{array}$ & $\begin{array}{l}\text { Std. Error of } \\
\text { the Estimate }\end{array}$ & $\begin{array}{l}\text { Unstandar } \\
\text { Coefficie }\end{array}$ & $\begin{array}{l}\text { rdized } \\
\text { nts B }\end{array}$ & $\begin{array}{c}\text { Standardized } \\
\text { Coefficients } \\
\text { Beta }\end{array}$ & $\mathrm{t}$ & P-value & Decision \\
\hline \multirow{2}{*}{ 1. PU } & \multirow{2}{*}{.214} & \multirow{2}{*}{.212} & \multirow{2}{*}{.44999} & Constant & 2.122 & \multirow{2}{*}{.463} & 15.518 & $.000 *$ & \multirow{2}{*}{$\begin{array}{c}\mathrm{H} 2 \mathrm{a} \\
\text { Supported }\end{array}$} \\
\hline & & & & PU & .328 & & 9.607 & $.000 *$ & \\
\hline \multirow[t]{2}{*}{ 2. PEOU } & \multirow{2}{*}{.187} & \multirow{2}{*}{.185} & \multirow{2}{*}{.45773} & Constant & 2.313 & \multirow{2}{*}{.433} & 18.160 & $.000 *$ & \multirow{2}{*}{$\begin{array}{c}\mathrm{H} 2 \mathrm{~b} \\
\text { Supported }\end{array}$} \\
\hline & & & & PEOU & .283 & & 8.824 & $.000 *$ & \\
\hline \multirow[t]{2}{*}{ 3. $1 Q$} & \multirow{2}{*}{.175} & \multirow{2}{*}{.172} & \multirow{2}{*}{.46126} & Constant & 2.385 & \multirow{2}{*}{.418} & 19.186 & $.000 *$ & \multirow{2}{*}{$\begin{array}{c}\mathrm{H} 2 \mathrm{c} \\
\text { Supported }\end{array}$} \\
\hline & & & & IQ & .270 & & 8.458 & $.000 *$ & \\
\hline \multirow[t]{2}{*}{ 4. SyQ } & \multirow{2}{*}{.236} & \multirow{2}{*}{.234} & \multirow{2}{*}{.44366} & Constant & 2.102 & \multirow{2}{*}{.486} & 16.103 & $.000^{*}$ & \multirow{2}{*}{$\begin{array}{c}\text { H2d } \\
\text { Supported }\end{array}$} \\
\hline & & & & Sya & .339 & & 10.231 & $.000 *$ & \\
\hline \multirow[t]{2}{*}{ 5. SvQ } & \multirow{2}{*}{$\begin{array}{c}.19 \\
1\end{array}$} & \multirow{2}{*}{.189} & \multirow{2}{*}{.45667} & Constant & 2.379 & \multirow{2}{*}{.437} & 20.068 & $.000 *$ & \multirow{2}{*}{$\begin{array}{c}\mathrm{H} 2 \mathrm{e} \\
\text { Supported }\end{array}$} \\
\hline & & & & $S v Q$ & .274 & & 8.933 & $.000 *$ & \\
\hline \multirow{2}{*}{$\begin{array}{l}\text { 6. Technical } \\
\text { Factors }\end{array}$} & \multirow[b]{2}{*}{.272} & \multirow[b]{2}{*}{.270} & \multirow[b]{2}{*}{.43330} & Constant & 1.853 & \multirow[b]{2}{*}{.521} & 13.132 & $.000 *$ & \multirow{2}{*}{$\begin{array}{c}\mathrm{H} 2 \\
\text { Supported }\end{array}$} \\
\hline & & & & $\begin{array}{l}\text { Technical } \\
\text { Factors }\end{array}$ & .404 & & 11.228 & $.000 *$ & \\
\hline
\end{tabular}

Source: Developed by the researchers based on regression analysis

Table 5 illustrates that $\mathrm{H} 2 \mathrm{a}, \mathrm{H} 2 \mathrm{~b}, \mathrm{H} 2 \mathrm{c}, \mathrm{H} 2 \mathrm{~d}$, and $\mathrm{H} 2 \mathrm{e}$ are supported and the variables associated with these sub-hypotheses are found to have a positive influence on citizens' trust in e-government since $p$-value is less than 0.05 . System quality hasthe strongest influence (standardized $\beta=0.486$ ), whereas information quality has the weakest influence (standardized $\beta=0.418$ ). Additionally, the overall influence of the technical factors have been found to be significant with $\beta=0.521$, thus supporting $\mathrm{H} 2$.

\subsubsection{Hypothesis $H 3$.}

The third hypothesis consists of two sub-hypotheses ( $\mathrm{H} 3 \mathrm{a}$ and $\mathrm{H} 3 \mathrm{~b}$ ). The results of the simple linear regression of each of these sub-hypotheses as well as the overall impact of Technical Factors are shown in Table (6). 
Table 6. Simple Linear Regression results of $\mathrm{H} 3$

\begin{tabular}{|c|c|c|c|c|c|c|c|c|c|}
\hline Influence & $R^{2}$ & $\begin{array}{c}\text { Adjuste } \\
d R^{2}\end{array}$ & $\begin{array}{l}\text { Std. Error of } \\
\text { the Estimate }\end{array}$ & $\begin{array}{r}\text { Unstandard } \\
\text { Coefficient }\end{array}$ & $\begin{array}{l}\text { lized } \\
\text { ts B }\end{array}$ & $\begin{array}{c}\text { Standardized } \\
\text { Coefficients } \\
\text { Beta }\end{array}$ & $\mathrm{t}$ & $\begin{array}{c}\mathrm{P}- \\
\text { value }\end{array}$ & Decision \\
\hline \multirow{2}{*}{ 1. PExp } & \multirow{2}{*}{.267} & \multirow{2}{*}{.265} & \multirow{2}{*}{.43464} & Constant & 2.137 & \multirow{2}{*}{.517} & 18.178 & $.000 *$ & \multirow{2}{*}{$\begin{array}{c}\text { H3a } \\
\text { Supported }\end{array}$} \\
\hline & & & & PExp & .333 & & 11.101 & $.000 *$ & \\
\hline \multirow[t]{2}{*}{ 2. GRep } & \multirow{2}{*}{.234} & \multirow{2}{*}{.231} & \multirow{2}{*}{.44449} & Constant & 2.450 & \multirow{2}{*}{.483} & 24.971 & $.000 *$ & \multirow{2}{*}{$\begin{array}{c}\text { H3b } \\
\text { Supported }\end{array}$} \\
\hline & & & & Grep & .267 & & 10.149 & $.000 *$ & \\
\hline \multirow{2}{*}{$\begin{array}{l}\text { 3. Governmental } \\
\text { Factors }\end{array}$} & \multirow[b]{2}{*}{.296} & \multirow[b]{2}{*}{.294} & \multirow[b]{2}{*}{.42598} & Constant & 2.099 & \multirow[b]{2}{*}{.544} & 18.615 & $.000 *$ & \multirow{2}{*}{$\begin{array}{c}\text { H3 } \\
\text { Supported }\end{array}$} \\
\hline & & & & $\begin{array}{l}\text { Governmenta } \\
\text { I Factors }\end{array}$ & .353 & & 11.923 & $.000 *$ & \\
\hline
\end{tabular}

Table 6 illustrates that the two sub-hypotheses ( $\mathrm{H3a}, \mathrm{H} 3 \mathrm{~b}$ ) that composite H3are supported and the variables associated with these sub-hypotheses are found to have a positive influence on citizens' trust in e-government since $p$-value is less than 0.05 for both variables. Past experience has a stronger influence (standardized $\beta=0.517$ ) than government reputation (standardized $\beta=0.483$ ) Additionally, the overall influence of the governmental factors have been found to be significant ( $\beta$ $=0.544)$, thus supporting $\mathrm{H} 3$.

\subsubsection{Hypothesis H4.}

The fourth hypothesis consists of two sub-hypotheses ( $\mathrm{H} 4 \mathrm{a}$ and $\mathrm{H} 4 \mathrm{~b}$ ). The results of the simple linear regression of each of these sub-hypotheses as well as the overall impact of Risk Factors are shown in Table (7).

Table 7. Simple Linear Regression results of $\mathrm{H} 4$

\begin{tabular}{|c|c|c|c|c|c|c|c|c|c|}
\hline Influence & $\mathrm{R}^{2}$ & $\begin{array}{c}\text { Adjuste } \\
\mathrm{d} \mathrm{R}^{2}\end{array}$ & $\begin{array}{l}\text { Std. Error of } \\
\text { the Estimate }\end{array}$ & $\begin{array}{r}\text { Unstanc } \\
\text { Coeffic }\end{array}$ & $\begin{array}{l}\text { rdized } \\
\text { nts B }\end{array}$ & $\begin{array}{c}\text { Standardized } \\
\text { Coefficients } \\
\text { Beta }\end{array}$ & $\mathrm{t}$ & P-value & Decision \\
\hline \multirow{2}{*}{ 1. Pri } & \multirow{2}{*}{.046} & \multirow{2}{*}{.043} & \multirow{2}{*}{.49602} & Constant & 3.855 & \multirow{2}{*}{-.213} & 34.170 & $.000 *$ & \multirow{2}{*}{$\begin{array}{c}\mathrm{H} 4 \mathrm{a} \\
\text { Supported }\end{array}$} \\
\hline & & & & Pri & -.195 & & -4.018 & $.000^{*}$ & \\
\hline \multirow[t]{2}{*}{ 2. Sec } & \multirow[b]{2}{*}{.003} & \multirow[b]{2}{*}{.000} & \multirow[b]{2}{*}{.50694} & Constant & 3.307 & \multirow[b]{2}{*}{.055} & 30.156 & .000 & \multirow{2}{*}{$\begin{array}{c}\text { H4b } \\
\text { Not } \\
\text { Supported }\end{array}$} \\
\hline & & & & Sec & .030 & & 1.022 & .308 & \\
\hline \multirow[b]{2}{*}{ 3. Risk Factors } & \multirow[b]{2}{*}{.004} & \multirow[b]{2}{*}{.001} & \multirow[b]{2}{*}{.50669} & Constant & 3.595 & \multirow[b]{2}{*}{-.064} & 23.045 & $.000^{*}$ & \multirow{2}{*}{$\begin{array}{c}\text { H4 } \\
\text { Supported }\end{array}$} \\
\hline & & & & $\begin{array}{l}\text { Risk } \\
\text { Factors }\end{array}$ & -.062 & & $\mid-1.173$ & $.000 *$ & \\
\hline
\end{tabular}

Source: Developed by the researchers based on regression analysis

Table 7 illustrates that H4ais supported whereas $\mathrm{H} 4 \mathrm{~b}$ is not. The respondents concerns about their privacy and their fear from any possible violations of their personal data negatively influence their trust level towards using e-government services (standardized $\beta=-0.213$ ). On the other hand, surprisingly security issues have been found to be insignificant ( $p$-value $>0.05$ ). Respondents concerns about the level of security associated with their transactions with e-government has a minor correlation with their trust in e-government (standardized $\beta=0.055$ ). The overall influence of 
the governmental factors have been found to be significant with a negative influence on trust in egovernment $(\beta=-0.064)$, thus supporting $\mathrm{H} 4$.

\subsubsection{Hypothesis $\mathrm{H} 5$.}

The fifth hypothesis test the influence of the respondents propensity to trust in technology on their trust in e-government. The results of the simple linear regression are shown in Table (8).

Table 8. Simple Linear Regression results of H5

\begin{tabular}{|c|c|c|c|c|c|c|c|c|c|}
\hline Influence & $\mathrm{R}^{2}$ & $\begin{array}{l}\text { Adjuste } \\
\mathrm{d} \mathrm{R}^{2}\end{array}$ & $\begin{array}{l}\text { Std. Error of } \\
\text { the Estimate }\end{array}$ & $\begin{array}{l}\text { Unstanda } \\
\text { Coefficie }\end{array}$ & $\begin{array}{l}\text { rdized } \\
\text { nts B }\end{array}$ & $\begin{array}{c}\text { Standardized } \\
\text { Coefficients } \\
\text { Beta }\end{array}$ & $\mathrm{t}$ & P-value & Decision \\
\hline \multirow{2}{*}{ 1. PTrst } & \multirow{2}{*}{.180} & \multirow{2}{*}{.178} & \multirow{2}{*}{.77058} & Constant & 2.499 & \multirow{2}{*}{.424} & 22.896 & $.000 *$ & \multirow{2}{*}{$\begin{array}{c}\text { H5 } \\
\text { Supported }\end{array}$} \\
\hline & & & & PTrst & .253 & & 8.619 & $.000 *$ & \\
\hline
\end{tabular}

*significant at $\alpha=0.05$; Dependent Variable is Trust in e-government (TrstinG)

Source: Developed by the researchers based on regression analysis

Table 8 illustrates that propensity to trust in technology has a positive influence on citizens' trust in e-government (standardized $\beta=0.424$ ). Thus, supporting $\mathrm{H} 5$.

\subsubsection{Multiple Linear Regression}

The researchers used multiple linear regression to examine the combined influence of technical factors, governmental factors, risk factors, propensity to trust in technology and their interactions on employees' trust in e-government. Table (9), Table (10) and Table (11) summarize the results:

Table 9. Model Summary

\begin{tabular}{|c|c|c|c|c|}
\hline Model & $R$ & $R$ Square & $\begin{array}{c}\text { Adjusted R } \\
\text { Square }\end{array}$ & $\begin{array}{c}\text { Std. Error of } \\
\text { the Estimate }\end{array}$ \\
\hline 1 & $.592^{\mathrm{a}}$ & .350 & .343 & .41102 \\
\hline
\end{tabular}

Source: Developed by the researchers based on regression analysis

Table 10. ANOVA

\begin{tabular}{|l|c|c|c|c|c|}
\hline Model & Sum of Squares & Df & Mean Square & $F$ & P-value \\
\hline 1 Regression & 30.538 & 4 & 7.634 & 45.192 & $.000^{\text {a }}$ \\
Residual & 56.593 & 335 & .169 & & \\
Total & 87.131 & 339 & & & \\
\hline
\end{tabular}

a. Predictors: (Constant), PTrst, Risk_Factors, Technical_Factors, Governmental_Factors

b. Dependent Variable: TrstinG

Source: Developed by the researchers based on regression analysis

As shown in Table (10), the overall model is significant $(\mathrm{F}=45.192, \mathrm{p}$-value $=0.000)$ which indicate a good fit of the data, Table (9) shows that the determination factor R2 is equal to $35 \%$, which means that the examined constructsexplain about $35 \%$ of the change in citizens' trust in e-government. Table (11) illustrates the influence of each independent construct, the largest influence is for the governmental factors (standardized $\beta=-0.303$, $p$-value $=0.000$ ), followed by technical factors(standardized $\beta=0.247, p$-value $=0.000$ ), then risk factors (standardized $\beta=-0.144, p$-value $=0.000$ ) and finally propensity to trust in technology (standardized $\beta=0.122, p$-value $=0.051$ ). Although that propensity to trust in technology is found to be significant when examined separately, in the multiple regression model it becomes insignificant ( $P$-value $>0.05)$ this significance is undermined by the effect of other independent variables. 
Table 11. Coefficients of Multiple Regression Model

\begin{tabular}{|c|c|c|c|c|c|c|c|}
\hline \multirow[b]{2}{*}{ Model } & \multicolumn{2}{|c|}{$\begin{array}{l}\text { Unstandardized } \\
\text { Coefficients }\end{array}$} & \multirow{2}{*}{$\begin{array}{c}\text { Standardized } \\
\text { Coefficients }\end{array}$} & \multirow[b]{2}{*}{$\mathrm{t}$} & \multirow[b]{2}{*}{ P-value } & \multicolumn{2}{|c|}{$\begin{array}{l}\text { Collinearity } \\
\text { Statistics }\end{array}$} \\
\hline & B & Std. Error & & & & Tolerance & VIF \\
\hline (Constant) & 2.106 & .172 & & 12.243 & .000 & & \\
\hline Technical_Factors & .192 & .054 & .247 & 3.542 & .000 & .398 & 2.511 \\
\hline $\begin{array}{l}\text { Governmental_Fact } \\
\text { ors }\end{array}$ & .197 & .046 & .303 & 4.265 & .000 & .383 & 2.608 \\
\hline Risk_Factors & -.139 & .043 & -.144 & -3.224 & .001 & .976 & 1.024 \\
\hline PTrst & .067 & .034 & .112 & 1.955 & .051 & .593 & 1.688 \\
\hline
\end{tabular}

a. Dependent Variable: TrstinG

Source: Developed by the researchers based on regression analysis

Based on the multiple regression analysis results, Equation (1) is formulated which predicts the employees trust level in e-government using the three significant constructs:

$$
\begin{gathered}
\text { Citizens' Trust in e-government }=2.106+0.192 \text { Technical_Factors }+0.197 \text { Governmental_ } \\
\text { Factors }+0.139 \text { Risk_Factors }
\end{gathered}
$$

The Variance Inflation Factor (VIF) is calculated as shown in the last right column of Table (11) to ensure that no multicolliearity exists between the independent variables. As values of VIF's are less than 5, nocollinearity exist between the independent variables (Rogerson, 2001).

\section{Discussion}

Many researchers have examined the factors that contribute in the adoption of e-government in many countries. This study integrated four constructs (technical factors, governmental factors, risk factors, and propensity to trust in technology) in addition to the demographic characteristics of the citizens participating in the study. Regarding the demographic characteristics, the findings showed unexpected results as no statistically significant differences in the level of citizens' trust in egovernment according to these characteristicswere found. Concerning gender, the findings matches the findings of Colesca (2009), AlAwadhi (2019), and Alzahrani et al, (2018) who indicated that the difference between males and females is not significant. One possible reason for this insignificance is that the use of internet and internet-supported systems is accessible for both males and females; therefore gender is no more a determining factor (Lavanya and Karthikeyan, 2016). On the other hand, it contradicts the findings of Venkatesh\&Venkatraman (2014) who pointed that men tend to trust in e-government more than women do; as well as Mutimukwe, Kolkowska\&Grönlund (2017) who found that men were more reluctant to use e-government services than women. For Age, the results of the current study contradicts the findings of Colesca (2009) who found that age negatively influence trust level in e-government, while matches the findings ofAlAwadhi (2019). For the third demographic characteristic, educational level, the current study results coincide with the results ofAlAwadhi (2019) and Colesca (2009) who did not find significant differences. This could be justified as the opportunity of using these services is opened to all employees at the same degree, therefore citizens judge and consequently trust in e-government services based on their own experiences with the system. This result is opposite to the findings of Venkatesh\&Venkatraman (2014)who pointed that educational level positively influence trust level in e-government, and Sharma(2015) who had shown that the respondents' educational level determined their willingness to adopt and use egovernment service in Oman.Relating to monthly income, the findings support the findings of (Colesca, 2009) and not supporting the findings of Venkatesh\&Venkatraman (2014) who indicated that monthly income positively influence trust level in e-government services. For the last characteristic internet experience, the results are contradictory to the findings of Colseca (2009), 
Beldad et al, (2012), and Alzahrani et al, (2018) who stated that respondents with greater experience show more trust in e-government. On the other hand, these findings are in line with the findings of Abu-Shanab (2019).

After all, despite the fact that no significant statistical differences exist, Table (4) shows that mean scores are mostly high $(3.41<=$ score $<=4.2)$, with some moderate scores $(2.61<=$ score $<=3.4)$ particularly for citizens with internet experience less than one year. This indicate that citizens in general have a positive attitude towards trusting e-government services.

For the second hypothesis, the findings revealed that technical factors significantly influence trust level in e-government. This result seems logical, when the system that provides the intended service is useful, easy to use, availing accurate and timely information, reliable, and responsive to the users' enquiries, the users' trust level in the system is expected to rise. The current study examined five technical factors (perceived usefulness, perceived ease of use, system quality, service quality and information quality), the findings relating to system quality, service quality and information quality are in line with the findings of Alzahrani et al, (2018). The findings concerning the other two factors are supported by the findings of Colseca (2009) who found that perceived usefulness positively influence trust in e-government, and Chen \&Aklikokou (2019) who found a significant influence of perceived ease of use on intention to use e-government system.

Governmental factors in the current study have the strongest influence of the citizenstrust in egovernment. This result is consistent with Beldad et al, (2012) and Alzahrani et al, (2018). Governments have a critical role in gaining users' trust in the e-government system and maintaining these users as regular ones. This could be achieved by providing high quality services to the users particularly those who are new to the system, as the users' past experience is a determining factor of trust. Furthermore, government reputation is also vital for encouraging users to use e-government services, if the government agencies are trustworthy in the traditional form of providing services through offices and departments, this may positively influence their e-services, particularly that colseca (2009) revealed that perceived governmental trustworthiness will positively influence the trust in e-government services.

Regarding risk factors, two variables are included in the current study: privacy and security concerns. Privacy concerns are found to negatively influence trust level in e-government, thus supporting $\mathrm{H} 4 \mathrm{a}$. Citizens' concerns about their personal information and the possibility of using these information either intentionally or accidently by other parties undermine their trust level in egovernment. As the users of the system perceive that their information are secured enough and cant be used in any actions that violate specifics laws their trust in the e-government is enhanced (Elsofany, Al-Tourki, Al-Howimel\& Al-Sadoon, 2012).This complies with the findings of previous research such as Alzahrani et al (2018) and Colseca (2009); but contradicts the finding of Malik, Shuqin, Mastoi, Gul, \& Gul (2016)who found that privacy and security issues were not among the significant predictors of Pakistani citizens' satisfaction towards e-government portal.

Regarding security issues, previous research showed mixed results, while some studies found a negative significant influence of security issues on trusting e-government services (Alzahrani et al, 2018), others found either no influence or positive influence (Malik et al, 2016; Beldad et al. 2012). The findings of the current study regarding security could be justified as the respondents are not aware of the technical security procedures implemented by the government that ensure safe transactions, uploading and transfer of data. Although that security concerns are not significant, the overall influence of risk factors is significant.

As for the last independent variable, propensity to trust in technology, the findings show that it has a significant positive influence on citizens' trust in e-government when examined alone. In the multiple regression model, this influence has become insignificant. 


\section{Conclusion}

Governments in the Middle East region are employing information and communications technologies in their processes to deliver services to their citizens. Trust in these technologies and the e-government portals is a corner stone in the citizens' acceptance and participation in these services. This study aimed to explore the antecedents of trust in e-government from citizens' perspective. The proposed model hypothesized four relationships between four selected constructs as well as five demographic characteristics. The researchers analyzed the gathered data using simple and multiple regression analysis. with respect to demographic characteristics, despite that fact that no significant statistical differences exist in trust level in e-government among the respondents, but the trust in e-government scores were high reflecting that employees are trusting in the egovernment.

With regard to the influence of each independent construct, all of the proposed constructs significantly influenced trust level in e-government when examined separately. Whereas only technical factors, governmental factors and risk factors had significant influence on trust level since propensity to trust in technology impact was eliminated by the other factors. Consequently, the paper concludes that technical factors and governmental factors positively influence trust level ingovernment, whereas risk factors had a negative influence on trust level. As the Palestinian government have started implementing e-government service in the public sector, understanding the impact of the examined constructs in this study would help in improving these services and ultimately achieving a higher level of trust among the citizens. Enhancing security measures adopted on the e-government portals would raise the level of trust and encourage the citizens to participate in e-government transactions that require the disclosure of personal information. Supporting the egovernment portals with the necessary trustworthiness cues as an easy to read and understand, available and findable privacy statement may enhance the level of trust towards the e-government services.

\section{Funding}

This research did not receive any specific grant from funding agencies in the public, commercial, or not-for-profit sectors.

\section{Conflict of interest}

The authors declare that no competing financial interests or personal relationships that could influence this paper exist.

\section{References}

1. Abu-Shanab, E. (2014). Antecedents of trust in e-government services: an empirical test in Jordan. Transforming Government: People, Process and Policy, 8(4), 480-499.

2. Abu-Shanab, E. (2019). Predicting trust in e-government: two competing models. Electronic Government, an International Journal, 15(2), 129-143.

3. Abu-Shanab, E.A. (2017), E-government familiarity influence on Jordanians' perceptions. Telematics and Informatics, 34(1), 103-113.

4. Akbar, H. (2015). Factors influencing the process of e-government diffusion a conceptual framework. International Journal of Commerce and Management Research, 2(10), 62-67.

5. AlAwadhi, S. (2019, January). A Proposed Model of Trust Factors for E-government Adoption and Civic Engagement. In Proceedings of the 52nd Hawaii International Conference on System Sciences. 
6. Alomari, M. K., Sandhu, K., \& Woods, P. (2009, November). E-government adoption in the Hashemite Kingdom of Jordan: factors from social perspectives. In 2009 International Conference for Internet Technology and Secured Transactions (ICITST) (pp. 1-7). IEEE

7. Alomari, M.K., Sandhu, K. and Woods, P. (2014). Exploring citizen perceptions of barriers to egovernment adoption in a developing country. Transforming Government: People, Process and Policy, 8(1), 131-150.

8. Al-Samarraie, H., Teng, B. K., Alzahrani, A. I., \& Alalwan, N. (2018). E-learning continuance satisfaction in higher education: a unified perspective from instructors and students. Studies in higher education, 43(11), 2003-2019

9. Alsmadi, I., \& Abu-Shanab, E. (2016). E-government website security concerns and citizens' adoption. Electronic Government, an International Journal, 12(3), 243-255

10.Alzahrani, L., Al-Karaghouli, W., \&Weerakkody, V. (2016). Developing citizens' trust towards successful adoption of e-government: An empirical study from Saudi Arabia. Academy of Contemporary Research Journal, 5(2), 9-15.

11.Alzahrani, L., Al-Karaghouli, W., \&Weerakkody, V. (2017). Analyzing the critical factors influencing trust in e-government adoption from citizens' perspective: A systematic review and a conceptual framework. International Business Review, 26(1), 164-175.

12.Alzahrani, L., Al-Karaghouli, W., \&Weerakkody, V. (2018). Investigating the impact of citizens' trust toward the successful adoption of e-government: A multigroup analysis of gender, age, and internet experience. Information Systems Management, 35(2), 124-146.

13.Anderson, M. R. (2010). Community psychology, political efficacy, and trust. Political Psychology, 31(1), 59-84.

14.Ayyash, M. M., Ahmad, K., \& Singh, D. (2013). Investigating the effect of information systems factors on trust in e-government initiative adoption in Palestinian public sector. Research Journal of Applied Sciences.Engineering and Technology, 5(15), 3865-3875.

15.Gracia, D. B., \&Arino, L. C. (2015). Rebuilding public trust in government administrations through e-government actions. Revista Española de Investigación de Marketing ESIC, 19(1),1-11.

16.Bélanger, F., \& Carter, L. (2008). Trust and risk in e-government adoption. The Journal of Strategic Information Systems, 17(2), 165-176.

17.Beldad, A., van der Geest, T., de Jong, M., \&Steehouder, M. (2012). A cue or two and I'll trust you: Determinants of trust in government organizations in terms of their processing and usage of citizens' personal information disclosed online. Government information quarterly, 29(1), 41-49.

18.Cetin, Y., Kanat, I., \&Ozkan, S. (2011). Systematic Review Of E-Government Adoption Research, tGov Workshop'11 (tGOV11) March 17-18, 2011. Brunel University, West London, 1-22.

19.Chen, L., \& Aklikokou, A. K. (2019). Determinants of E-government Adoption: Testing the Mediating Effects of Perceived Usefulness and Perceived Ease of Use. International Journal of Public Administration, 1-16.

20.Choudrie, J., Alfalah, A., \& Spencer, N. (2017). Older Adults Adoption, Use and Diffusion of EGovernment Services in Saudi Arabia, Hail City: A Quantitative Study. Paper presented at the 50th Hawaii International Conference on System Sciences, University of Hawaii, Honolulu.

21.Colquitt, J. A., Scott, B. A., \&LePine, J. A. (2007). Trust, trustworthiness, and trust propensity: A meta-analytic test of their unique relationships with risk taking and job performance. Journal of applied psychology, 92(4), 909.

22. Colesca, S. E. (2009). Understanding trust in e-government. Engineering Economics, 63(4), 7-15.

23.Colesca, S. E., \&Dobrica, L. (2008). Adoption and use of e-government services: The case of Romania. Journal of applied research and technology, 6(3), 204-217.

24.Daniel, W. W., \&Cross, C. L. (2013). Biostatistics: A Foundation for Analysis in theHealth Sciences. Hoboken, New Jersey: Wiley.

25.Dwivedi, Y. K., Weerakkody, V., \& Janssen, M. (2012). Moving towards maturity: challenges to successful e-government implementation and diffusion. ACM SIGMIS Database: the DATABASE for Advances in Information Systems, 42(4), 11-22. 
26.Ejdys, J., Ginevicius, R., Rozsa, Z., \&Janoskova, K. (2019). The role of perceived risk and security level in building trust in e-government solutions. Economics and Management 22(3), 220-235.

27.El-sofany, H. F., Al-Tourki, T., Al-Howimel, H., \& Al-Sadoon, A. (2012). E-Government in Saudi Arabia: Barriers, challenges and its role of development. International Journal of Computer Applications, 48(5), 16-22.

28.Fakhoury, R., \& Aubert, B. (2015). Citizenship, trust, and behavioural intentions to use public eservices: The case of Lebanon. International Journal of Information Management, 35(3), 346-351.

29.General Personnel Council (2016). Retrieved from General Personnel Council https://gpc.pna.ps/diwan/index.gpc.

30.Khan, S., Rahim, N. Z. A., \&Maarop, N. (2018). The Influence of Trust in Understanding Citizens' Behavior to Use Social media for E-government Services. Open International Journal of Informatics (OIJI), 62-71.

31.Khan, S., Rahim, N. Z. A., \&Maarop, N. (2019). A Review On Antecedents Of Citizen's Trust In Government Social Media Services. Publishing Goal, 109

32.Khasawneh, R. T., \& Abu-Shanab, E. A. (2013). E-government and social media sites: the role and impact. World Journal of Computer Application and Technology, 1(1), 10-17.

33.Kurfalı, M., Arifoğlu, A., Tokdemir, G., \&Paçin, Y. (2017). Adoption of e-government services in Turkey. Computers in Human Behavior, 66, 168-178.

34.Lavanya, R. \&Karthikeyan, P. (2016). A Study on the Usage of Social Networking Sites among College Students with reference to Erode District. Asian Journal of Research in Social Sciences and Humanities. 6(6), 1230-1240.

35.Liu, Y., \& Zhou, C. (2010, July). A citizen trust model for e-government. In 2010 IEEE International Conference on Software Engineering and Service Sciences (pp. 751-754). IEEE.

36.Malik, B. H., Shuqin, C., Mastoi, A. G., Gul, N., \& Gul, H. (2016). Evaluating citizen e-satisfaction from e-government services: A case of Pakistan. European Scientific Journal, 12(5), 346-370.

37. Mensah, I. K. (2019). Factors Influencing the Intention of University Students to Adopt and Use EGovernment Services: An Empirical Evidence in China. SAGE Open, 9(2), 1-19.

38.Mensah, I. K., \&Mi, J. (2018). Exploring the Impact of Demographic Factors on E-Government Services Adoption. Information Resources Management Journal (IRMJ), 31(3), 1-16.

39.Mensah, I. K., \&Mi, J. (2019). Predictors of the Readiness to Use E-Government Services From Citizens' Perspective. International Journal of Technology Diffusion (IJTD), 10(1), 39-59.

40.Ministry of Health. Annual Report (2019). Retrieved from https://site.moh.ps/index/Books/BookType/2/Language/ar

41.Mohajerani, S., Shahrekordi, S. Z., \&Azarlo, M. (2015, April). The impact of privacy and security concerns, trust in technology and information quality on trust in e-government and intention to use e-government. In 2015 9th International Conference on e-Commerce in Developing Countries: With focus on e-Business (ECDC) (pp. 1-6). IEEE.

42.Morgeson III, F. V., VanAmburg, D., \&Mithas, S. (2010). Misplaced trust? Exploring the structure of the e-government-citizen trust relationship. Journal of Public Administration Research and Theory, 21(2), 257-283.

43.Mutimukwe, C., Kolkowska, E., \&Grönlund, Å. (2017, September). Trusting and adopting Egovernment services in developing countries? Privacy concerns and practices in Rwanda. In International Conference on Electronic Government (pp. 324-335). Springer, Cham

44.Nunnaly, J. (1978). Psychometric theory. New York: McGraw-Hill.

45.Obaid, T., Abu Mdallalah, S., Jouda, H., \& Abu Jarad, A. (2020). Factors for Successful EGovernment Adoption in Palestine: A Conceptual Framework. The 1st international Conference on Information Technology and Business ICITB2020 (July 25, 2020).

46.Osman, I. H., Anouze, A. L., Irani, Z., Al-Ayoubi, B., Lee, H., Balcı, A.\&Weerakkody, V. (2014). COBRA framework to evaluate e-government services: A citizen-centric perspective. Government information quarterly, 31(2), 243-256. 
47.Rana, N.P. and Dwivedi, Y.K., (2015). Citizen's adoption of an e-government system: Validating extended social cognitive theory (SCT). Government Information Quarterly,32(2), 172-181

48.Rehouma, M. B., \& Hofmann, S. (2018, May). Government employees' adoption of information technology: a literature review. In Proceedings of the 19th Annual International Conference on Digital Government Research: Governance in the Data Age (p. 43). ACM.

49.Rogerson, P. A. (2001). Statistical methods for geography. London: Sage

50.Rose, J., Persson, J., Heeager, L., \&Irani, Z. (2015). Managing e-Government: value

51.positions and relationships. Information Systems Journal, 25, 531-571.

52.Saeed, S., Shaikh, A., \& Memon, M. A. (2018). Impact of Social Networking Sites on Personality \& Attitude of Young Adults (Research covering the young adults" lives within Korangi, Karachi). International Research Journal of Arts \& Humanities (IRJAH), 46(46).

53.Santhanamery, T., \&Ramayah, T. (2018). Trust in the system: The mediating effect of perceived usefulness of the e-filing system. In S. Saeed, T. Ramayah, \& Z. Mahmood (Eds.), User centric egovernment. Integrated series in information systems. Springer, Cham

54.Shareef, M. A., Kumar, V., Kumar, U., \&Dwivedi, Y. K. (2011). E-Government Adoption Model (GAM): Differing service maturity levels. Government Information Quarterly, 28(1), 17-35.

55.Sharma, S. K. (2015). Adoption of e-government services: The role of service quality dimensions and demographic variables. Transforming Government: People, Process and Policy, 9(2), 207-222.

56.Singh, H., Das, A., \& Joseph, D. (2007). Country-level determinants of e-government maturity. Communications of the Association for Information Systems, 20(1), 40.

57.Srivastava, S. C., \&Teo, T. (2005). Citizen trust development for e-government adoption: Case of Singapore. PACIS 2005 Proceedings, 59.

58.Teo, T. S., Srivastava, S. C., \& Jiang, L. (2008). Trust and electronic government success: An empirical study. Journal of management information systems, 25(3), 99-132.

59.Veeramootoo, N., Nunkoo, R., \&Dwivedi, Y. K. (2018). What determines COBRA framework to evaluate e-government services: A citizen-centric perspective success of an e-government service? Validation of an integrative model of e-filing continuance usage. Government Information Quarterly, 35(2), 161-174.

60.Venkatesh, V., Sykes, T. A., \&Venkatraman, S. (2014). Understanding e-Government portal use in rural India: role of demographic and personality characteristics. Information Systems Journal, 24(3), 249-269.

61.Wang, T., \& Lu, Y. F. (2011). A study on determinants of initial trust on e-government. Value Engineering (in Chinese), 30(1), 171-173.

62.Wirtz, B. W., \&Daiser, P. (2018). A meta-analysis of empirical e-government research and its future research implications. International Review of Administrative Sciences, 84(1), 144-163.

63.Yildiz, M. (2007). E-government research: Reviewing the literature, limitations, and ways forward. Government Information Quarterly, 24(3), 646-665. doi:10.1016/j. giq.2007.01.002 